\title{
SISTEM PENGENDALIAN MANAJEMEN \\ PT. KALBE FARMA
}

\section{Djoko Sigit Gunanto}

Akademi Akuntansi Surakarta

\begin{abstract}
ABSTRAK
Strategi korporat yang dikembangkan adalah perusahaan dengan diversifikasi berhubungan. Perusahaan menetapkan strategi pengembangan ke arah bisnis internasional dan peningkatan kemampuan risetnya maka pada tingkat unit bisnis strategi yang diterapkan adalah "membangun". Strategi tersebut sesuai diterapkan bagi perusahaan yang ekspansi dan menghadapi situasi ketidakpastian yang lebih tinggi.

Penggunaan sumber daya yang sama dan terintegrasi seperti pemasaran, fasilitas produksi, keuangan serta fasilitas riset dan pengembangan oleh beberapa unit usaha yang ada telah menciptakan sinergi operasi

Proses perencanaan strategis dilakukan secara vertikal maupun horizontal mengingat tingginya tingkat keterkaitan antar unit. Proses perencanaan ditetapkan dari tingkat korporat kemudian tiap unit bisnis mengajukan rencana strategisnya yang mendukung strategi korporat untuk disetujui manajemen puncak.

Penilaian kinerja yang dilakukan dengan balaced scorcard. PT Kalbe Farma Tbk melakukan penilaian secara berkala terhadap kompensasi karyawan guna menjaga kesetaraan dengan standar industri. Standar keselamatan dan kesehatan kerja dalam semua aspek produksi juga ditingkatkan untuk mencapai kesejahteraan karyawan yang optimal.
\end{abstract}

Kata Kunci : Strategi perusahaan, Balanced Scorecard.

\section{PENDAHULUAN}

Didirikan pada tahun 1966, PT Kalbe Farma Tbk. telah jauh berkembang dari awal mulanya sebagai usaha farmasi yang dikelola di garasi rumah pendirinya di wilayah Jakarta Utara. Selama lebih dari 40 tahun sejarah Perseroan, pengembangan usaha telah gencar dilakukan melalui akuisisi strategis terhadap perusahaanperusahaan farmasi lainnya, membangun merekmerek produk yang unggul dan menjangkau pasar internasional dalam rangka transformasi Kalbe menjadi perusahaan produk kesehatan serta nutrisi yang terintegrasi dengan daya inovasi, strategi pemasaran, pengembangan merek, distribusi, kekuatan keuangan, keahlian riset dan pengembangan serta produksi yang sulit ditandingi dalam mewujudkan misinya untuk meningkatkan kesehatan untuk kehidupan yang lebih baik.

Grup Kalbe telah menangani portofolio merek yang handal dan beragam untuk produk obat resep, obat bebas, minuman energi dan nutrisi, yang dilengkapi dengan kekuatan bisnis usaha 
kemasan dan distribusi yang menjangkau lebih dari

1 juta outlet. Perseroan telah berhasil memposisikan merek-mereknya sebagai pemimpin di dalam masing-masing kategori terapi dan segmen industri tidak hanya di Indonesia namun juga di berbagai pasar internasional, dengan produk-produk kesehatan dan obat-obatan yang telah senantiasa menjadi andalan keluarga seperti Promag, Mixagrip, Woods, Komix, Prenagen dan Extra Joss. Lebih jauh, pembinaan dan pengembangan aliansi dengan mitra kerja internasional telah mendorong pengembangan usaha Kalbe di pasar internasional dan partisipasi dalam proyekproyek riset dan pengembangan yang canggih serta memberi kontribusi dalam penemuan terbaru di dalam bidang kesehatan dan farmasi termasuk riset sel punca dan kanker.

\section{Pelaksanaan konsolidasi Grup pada} tahun

2005 telah memperkuat kemampuan produksi, pemasaran dan keuangan Perseroan sehingga meningkatkan kapabilitas dalam rangka memperluas usaha Kalbe baik di tingkat lokal maupun internasional. Saat ini, Kalbe adalah salah satu perusahaan farmasi terbesar di Asia Tenggara yang sahamnya telah dicatat di bursa efek dengan nilai kapitalisasi pasar di atas US\$ 1 miliar dan penjualan melebihi Rp 7 triliun. Posisi kas yang sangat baik saat ini juga memberikan fleksibilitas yang luas dalam pengembangan usaha Kalbe di masa mendatang.

PT. Kalbe Farma terbagi menjadi tiga divisi yaitu divisi farmasi yang dikelola oleh anak perusahaan Kalbe Farma seperti Dankos, Innogene Kalbiotech, divisi makanan yang dikelola oleh PT. Sanghiyang Perkasa, PT Helios, dan divisi kemasan (packaging) yang dikelola anak perusahaan seperti Kageo Igar Jaya, PT Avesta Continental dan lain sebagainya.

\section{Tinjauan Umum Sistem \\ Pengendilan \\ Manajemen}

Pengendalian manajemen merupakan keharusan dalam suatu organisasi yang mempraktekkan desentralisasi. Salah satu pandangan berargumentasi bahwa sistem pengendalian manajemen harus sesuai dengan strategi perusahaan sehingga strategi menentukan desain sistem pengendalian manjemen. Hal ini terjadi bila perusahaan beroperasi pada konteks industri yang perubahan lingkungannya dapat diprediksi. Satu perspektif lain mengatakan bahwa strategi muncul melalui eksperimantasi yang dipengaruhi oleh manajemen perusahaan. Sehingga sistem pengendalian manjemen dapat mempengaruhi perkembangan strategi. Hal ini terjadi pada konteks perusahaan beroperasi pada lingkungan yang cepat berubah sehingga sulit merumuskan strategi terlebih dahulu.

Suatu sistem merupakan cara tertentu untuk melaksanakan suatu atau serangkaian aktivitas. Pengendalian manajemen adalah proses dimana seorang manajer mempengaruhi anggota organisasi lainnya untuk melaksanakan strategi organisasi. Sistem yang digunakan oleh manajemen untuk mengendalikan aktivitas suatu organisasi disebut sistem pengendalian manajemen. Pengendalian Manajemen difasilitasi oleh suatu sistem formal yang merupakan siklus aktivitas yang terus berulang.

\section{a. Lingkungan pengendalian manjemen}

Lingkungan pengendalian manajemen meliputi strategi, perilaku individu dan organisasi serta pusat tanggung jawab. Kegiatan utama pengendalian manajemen adalah mengimplementasikan strategi-strategi. Sistem pengendalian manajemen merupakan alat untuk mengiplementasikan strategi. 
Sistem pengendalian manajemen yang baik mempengaruhi perilaku manusia sedemikian rupa sehingga memiliki tujuan yang selaras, artinya tindakan-tindakan individu yang dilakukan untuk meraih tujuantujuan pribadi juga membantu untuk mencapai tujuan organisasi. Dengan demikian tujuan sistem pengendalian manajemen adalah memastikan tingkat keselarasan tujuan yang tinggi. Faktor informal juga memberi pengaruh besar pada upaya meraih tujuan organisasi. Faktor terpenting adalah budaya organisasi. Selain faktor informal, aturan-aturan, tuntunantuntunan dan prosedur-prosedur yang membentuk sistem penggendalian secara formal juga turut mempengaruhi. Struktur organisasi ikut pula mempengaruhi rancangan sistem pengendalian manajemen.

Pusat tanggung jawab merupakan konteks tempat berlangsungnya proses pengendalian. Pusat tanggung jawab merupakan struktur sistem pengendalian dan pemberian tanggung jawab kepada sub unit organisasi yang harus mencerminkan strategi organisasi. Ada dua jenis pusat tanggung jawab yaitu pusat pendapatan dan pusat beban. Kinerja masing-masing pusat tanggung jawab dinilai berdasarkan efisiensi dan efektivitas.

\section{b. Proses pengendalian manajemen.}

Banyak proses pengendalian manajemen melibatkan interaksi informal antara seorang manajer dengan manajer lainnya atau antara seorang manajer dengan bawahannya. Akhir-akhir ini istilah management by walking around dimunculkan untuk memberitahuakan batapa pentingnya informasi ini. Informasi informal menjadi bagian dari suatu system perencanaan dan pengendalian formal. System semacam ini meliputi aktivitas berikut, yaitu perencanaan strategis, persiapan anggaran, pelaksanaan, dan evaluasi kinerja. Masing-masing aktivitas menuju aktivitas lainnya dalam suatu siklus yang tetap. Secara kolektif, aktivitas-aktivitas tersebut merupakan suatu rangkaian yang tertutup.

\section{c. Variasi}

Para perancang sistem pengendalian manajemen harus memperhatikan secara eksplisit konteks strategis di mana pengendalian diterapkan. Strategi yang dipilih oleh suatu perusahaan dapat disusun sepanjang suatu kontinum dengan perusahaan tunggal pada ekstrem dan perusahaan diversifikasi tidak berhubungan pada ekstrem yang lain. Proses pengendalian manajemen berbeda sesuai dengan strategi perusahaan dalam dimensi ini.

Unit bisnis memiliki misi yang dapat diklasifikasikan menjadi "membangun", "mempertahankan", atau "memanen", dan para manajernya juga dapat memutuskan untuk membangun keunggulan kompetitif berdasarkan biaya rendah atau diferensiasi.

Mengaitkan pengendalian ke strategi sebaiknya tidak digunakan dengan sikap yang mekanistik, hal ini hanyalah tendesi dan bukan kebenaran universal. Faktanya, sistem pengendalian harus didesain dalam konteks lingkungan eksternal, teknologi, strategi, struktur organisasi, budaya, dan gaya manajemen puncak yang unik dari organisasi tersebut.

\section{Strategi Perusahaan}

Tiap organisasi memiliki strategi yang berbeda, dan pengendalian harus disesuaikan dengan syarat strategi spesifik sehingga yang harus diperhatikan dalam desain sistem pengendalian adalah apakah perilaku yang didorong oleh sistem 
tersebut merupakan perilaku yang diperlukan oleh suatu strategi.

Walaupun ada banyak definisi berbeda, namun secara umum bahwa strategi mendeskripsikan arah umum yang akan dituju suatu organisasi untuk mencapai tujuan. Perusahaan mengembangkan strateginya dengan mencocokkan kompetensi intinya dengan peluang industri. Strategi dapat ditemukan dalam dua tingkatan, yaitu strategi korporat dan strategi unit bisnis.

\section{a. Strategi korporat}

Strategi korporat adalah mengenai keberadan di tengah-tengah bauran bisnis yang tepat. Sehingga strategi ini lebih berkenaan dengan di mana sebaiknya bersaing dalam industri tertentu. Pada tingkat korporat, masalahnya adalah definisi di mana perusahaan akan berpartisipasi dan penugasan antar bisnisbisnis tersebut. Analisis strategi tingkat korporat menghasilkan keputusan yang melibatkan bisnis yang akan ditambah, dipertahankan, ditekankan, dikurangi perhatiannya dan bisnis yang didivestasi.

Berkaitan dengan strategi korporat, PT Kalbe Farma Tbk termasuk kategori perusahan dengan diversifikasi berhubungan yang beroperasi dalam beberapa industri, dan unitunit usaha tersebut memperoleh manfaat dari seperangkat kompetensi yang umum yaitu farmasi dan produk kesehatan. Strategi korporat yang diterapkan adalah pengembangan bisnis internasional dan meningkatkan kemampuan riset.

Kedua strategi utama tersebut telah dilakukan secara simultan. Melalui Kalsolac, produk obat paten yang pertama, Perseroan memiliki potensi yang besar, bahkan di pasar internasional terutama di negara-negara berkembang dan secara signifikan menjadikan Kalbe sebagai produsen farmasi yang setara dengan perusahaan yang mempunyai reputasi internasional. Pemantapan posisi di pasar internasional juga dilakukan dengan penguatan infrastruktur. Fasilitas produksi Orange Kalbe di Nigeria yang dijadwalkan akan mulai beroperasi pada tahun 2008 bertujuan untuk memperkokoh keberadaan Kalbe di Afrika serta membuka peluang bisnis baru di daerah yang prospektif dengan memanfaatkan keahlian dan pengetahuan yang dimiliki Perseroan saat ini.

Sebagai investasi tambahan untuk kelangsungan peningkatan pendapatan di masa mendatang, Kalbe juga telah melanjutkan rencana pengembangan kemampuan riset dan pengembangan di tahun 2007, dengan pembukaan Stem Cell and Cancer Institute. Untuk mendukung kegiatan ini, Kalbe telah menyisihkan dana riset yang memadai serta memulai kegiatan operasional PT Cordlife Indonesia yang menyediakan fasilitas penyimpanan darah tali pusat yang pertama di Indonesia pada tanggal 30 September 2007. Kalbe terus mendorong usaha Manajemen dalam kegiatan riset dan pengembangan yang intensif di masa mendatang, karena melalui kemampuan riset yang optimal dapat dilahirkan inovasi untuk pengembangan produk yang canggih guna memenuhi kebutuhan konsumen yang luas dan terus berubah.

PT Kalbe Farma Tbk telah berada dalam bauran industri yang tepat. Strategi yang ditetapkan Kalbe telah mengarahkan perusahan melakukan langkah-langkah yang sesuai. Penggunaan sumber daya yang sama dan terintegrasi seperti pemasaran, fasilitas produksi, keuangan serta fasilitas riset dan pengembangan oleh beberapa unit usaha yang 
ada telah menciptakan sinergi operasi. Hal ini membantu perusahaan untuk memperoleh manfaat dari skala dan ruang lingkup ekonomi.

Penekanan pada peningkatan kemampuan riset sangat membantu perusahaan untuk tumbuh dan berkembang sebab perusahaan dengan diversifikasi berhubungan umumnya tumbuh secara internal melalui penelitian dan pengembangan. Selain itu, pengembangan strategi dari industri tunggal ke industri dengan difersifikasi berhubungan adalah langkah yang tepat karena penelitian menunjukkan bahwa perusahaan dengan difersifikasi berhubungan mencapai kinerja yang tertinggi. Perusahaan kategori ini mempunyai kemampuan untuk mentransfer kompetensi inti dari satu unit bisnis ke unit bisnis lainnya. Oleh karena itu, pertumbuhan berbasis kompetensi dan diversifikasi mempunyai potensi untuk berhasil.

Langkah pengintegrasian semua unit bisnis merupakan langkah yang baik karena perusahaan dengan diversifikasi berhubungan dapat mengeksploitasi sistem operasinya secara lintas unit bisnis. Sub industri yang dimasuki juga telah sesuai dengan kemampuan dan penguasaan teknologi oleh perusahaan.

\section{b. Strategi unit bisnis}

Persaingan antar perusahaan dengan diversifikasi tidak berlangsung pada tingkat korporat tetapi juga unit bisnis perusahaan dengan unit bisnis perusahaan lainnya. Perusahaan tidak menghasilkan laba dari dirinya sendiri, malainkan pendapatan dihasilkan dan biaya ditanggung dalam unitunit bisnis. Strategi unit bisnis berkenaan dengan bagaimana menciptakan dan memelihara keunggulan kompetitif dalam masing-masing industri yang telah dipilih oleh perusahaan untuk berpartisipasi. Strategi unit bisnis bergantung dari dua aspek yang berkaitan, yaitu misinya (tujuan keseluruhannya) dan keunggulan kompetitifnya (bagaimana sebaiknya unit bisnis bersaing dalam industrinya untuk melaksanakan misi).

Walaupun pilihan strategi berbeda pada tingkatan hirarkis yang berbeda, ada kebutuhan yang jelas untuk konsistensi dalam strategi di seluruh tingkatan unit bisnis dan organisasi keseluruhan (korporat). Pada sebagian besar unit usaha PT Kalbe Farma Tbk menerapkan strategi membangun dimana hal ini sesuai dengan misinya untuk meluaskan pasar menjadi bisnis global. Kemudian dalam hal keunggulan kompetitifnya, beberapa unit usaha menerapkan strategi generik biaya rendah terutama untuk produk obat-obatan serta nutrisi karena produk tersebut telah memimpin pasar. Sedangkan pada produk minuman energi menerapkan strategi diferensiasi untuk menguatkan loyalitas pelanggan karena munculnya banyak saingan produk sejenis yang berharga murah.

\section{Perencanaan Strategik}

Perencanaan strategis adalah proses memutuskan program-program yang dilaksanakan oleh organisasi dan perkiraan jumlah sumber daya yang akan dialokasikan ke setiap program selama beberapa tahun kedepan. Perencanaan strategis adalah sistematis sehingga ada proses perencanaan tahunan dan jadwal yang sudah ditentukan. Proses perencanaan strategis melibatkan manajemen senior dan manajer dari unit bisnis atau pusat tanggung jawab utama lainnya. Tujuan utamanya adalah untuk memperbaiki komunikasi antara eksekutif korporat dengan eksekutif unit bisnis dengan cara menyediakan rangkaian aktivitas terjadwal, melalui mana mereka dapat mencapai 
sekelompok tujuan dan rencana yang disetujui bersama.

Suatu rencana strategis menunjukkan implikasi, beberapa tahun kedepan, dari implementasi perusahaan. Dalam periode sejak rencana strategis dibuat, organisasi telah membuat keputusan investasi modal. Proses persetujuan investasi modal tidak mengikuti suatu jadwal yang telah ditentukan, manajer membuat keputusan itu segera setelah kebutuhan itu diidentifikasi. Perencanaan memasukkan ke dalam rencana strategis, implikasi dari keputusan-keputusan ini beserta asumsi dan pedoman mengenai kekuatankekuatan eksternal seperti inflasi, kebijakan internal, dan penetapan harga produk.

Menggunakan informasi ini, unit bisnis dan unit pendukung mengusulkan rencana strategis baru, dan hal ini didiskusikan mendalam dengan manajer senior. Jika rencana korporat yang dihasilkannya tidak mengindikasikan bahwa profitabilitas akan mencukupi, maka ada kesenjangan perencanaan, yang diatasi dengan iterasi kedua rencana strategis, yang kadang melibatkan pemotongan yang menyakitkan terhadap rencana unit bisnis. Beberapa teknik analitis, seperti analisis antai nilai dan perhitungan biaya berdasarkan aktivitas, dapat membantu dalam proses perencanaan strategis.

Dalam penyusunan perencanaan strategik PT Kalbe Farma Tbk tentunya melibatkan manajemen yang relevan dimana dewan komisaris sebagai pengendali utama dalam perencanaan strategik. Perencanaan strategik ini relatif sangat penting bagi perusahaan yang masih dalam taraf pengembangan ke bisnis internasional dimana akan banyak menghadapai ketadakpastian lingkungan sekitarnya.

\section{Penganggaran}

Anggaran merupakan alat penting untuk perencanaan dan pengendalian jangka pendek yang efektif dalam organisasi. Suatu anggaran operasi biasanya meliputi waktu satu tahun dan menyatakan pendapatan dan beban yang direncanakan untuk tahun itu. Penyusunan anggaran sebelumnya didahului perencanaan strategis yang menyediakan kerangka kerja dalam mana anggaran tahunan dikembangkan. Anggaran merupakan potongan satu tahun dari rencana strategis perusahaan.

Tujuan anggaran adalah untuk menyesuaikan dengan rencana strategis, membantu mengoordinasikan aktivitas dari beberapa bagian organisasi, menugaskan tanggung jawab kepada manajer dan memperoleh komitmen yang merupakan dasar untuk mengevaluasi kinerja aktual manajer.

Pada PT Kalbe Farma Tbk proses penyusunan anggaran dilakukan secara vertikal dimana tiap unit bisnis meberikan rencana anggaran yang disusun berdasarkan pedoman dari manajemen puncak untuk mendapatkan persetujuan.

\section{Penilaian Kinerja}

Tujuan dari sistem ukuran kinerja adalah untuk mengimplementasikan strategi. Dalam menetapkan sistem semacam itu, manajer senior memilih ukuran-ukuran yang paling mewakili strategi perusahaan. Ukuran-ukuran tersebut dapat dilihat sebagai faktor keberhasilan penting (critical success factor) masa kini dan masa depan. Jika ukuran-ukuran tersebut membaik, berarti perusahaan telah mengimplementasikan strateginya. Keberhasilan strategi bergantung pada kekuatannya. Sistem pengukuran kinerja hanyalah suatu mekanisme yang memperbaiki kemungkinan 
bahwa perusahaan tersebut akan dari empat perspektif untuk mengetahui kinerja mengimplementasikan strateginya dengan berhasil. perusahaan:

\section{Balanced Scorecard.}

\section{a. Perspektif keuangan}

Balanced scorcard adalah salah satu dari sistem pengukuran kinerja. Melalui system ini maka kinerja PT Kalbe Farma Tbk dapat diukur

\begin{tabular}{|c|c|c|c|c|c|c|}
\hline Rasio-rasio Keuangan (\%) & 2006 & 2005 & & & 2003 & Financial Ratios (\%) \\
\hline Marjin Laba Kotor & 50.70 & 51.04 & 50.47 & 48.56 & 56.21 & Gross Profit Margin \\
\hline Rasio Laba terhadap Aktiva & 13.73 & 14.63 & 13.51 & 10.65 & 13.19 & Return on Assets \\
\hline Rasio Laba terhadap Ekuitas & 20.84 & 22.59 & 26.84 & 28.19 & 38.95 & Return on Equity \\
\hline Rasio Lancar & 498.26 & 504.17 & 394.00 & 289.25 & 156.80 & Current Ratio \\
\hline Rasio Pinjaman terhadap Ekuitas & 9.27 & 12.64 & 43.71 & 91.41 & 121.32 & Debt to Equity \\
\hline Rasio Pinjaman terhadap Aktiva & 6.11 & 8.19 & 22.01 & 34.54 & 41.08 & Debt to Assets \\
\hline
\end{tabular}

Secara umum pencapaian kinerja keuangan selama 5 tahun terakhir tersebut relatif menurun, namun hal ini disebabkan karena situasi perekonomian dan kebijakan regulasi yang tidak begitu menguntungkan. Selain itu, penambahan investasi bagi pengembangan bisnis internasional serta peningkatan kemampuan riset menyebabkan penurunan tingkat pengembalian atas aktiva. Strategi ini memang ditujukan untuk jangka panjang sehingga belum terlihat peningkatan hasil kinerjanya pada saat ini.

\section{b. Perspektif pelanggan}

\begin{tabular}{|c|c|c|c|c|c|c|}
\hline & \multicolumn{2}{|c|}{2007} & \multicolumn{2}{|c|}{2006} & \multirow{2}{*}{$\begin{array}{c}\text { Naik/(Turun) } \\
\text { Increase/ } \\
\text { (Decrease) }\end{array}$} & \multirow{2}{*}{$\begin{array}{c}\text { Perubahan } \\
\text { Change } \\
(\%)\end{array}$} \\
\hline & $\begin{array}{l}\text { Rp miliar } \\
\text { Rp billion }\end{array}$ & $\%$ Total & $\begin{array}{l}\text { Rp miliar } \\
\text { Rp billion }\end{array}$ & $\%$ Total & & \\
\hline Obat Bebas / OTC & $1,053.9$ & 15.0 & 944.1 & 15.5 & 109.8 & 11.6 \\
\hline Nutrisi / Nutritional & $1,600.0$ & 22.8 & $1,322.5$ & 21.8 & 277.5 & 21.0 \\
\hline Minuman Energi / Energy Drink & 802.3 & 11.5 & 895.7 & 14.8 & $(93.4)$ & $(10.4)$ \\
\hline Total Produk Kesehatan / Total Consumer Health & $3,456.2$ & 49.3 & 3.162 .3 & 52.1 & 293.9 & 9.3 \\
\hline Obat Resep / Prescription & $1,806.3$ & 25.8 & $1,457.1$ & 24.0 & 349.2 & 24.0 \\
\hline Distribusi / Distribution & $1,468.4$ & 21.0 & $1,205.9$ & 19.9 & 262.5 & 21.8 \\
\hline Kemasan / Packaging & 274.0 & 3.9 & 246.2 & 4.0 & 27.8 & 11.3 \\
\hline $\begin{array}{l}\text { Total Distribusi dan Kemasan / Total Distribution and } \\
\text { Packaging }\end{array}$ & $1,742.4$ & 24.9 & $1,452.1$ & 23.9 & 290.3 & 20.0 \\
\hline Penjualan Bersih / Net Sales & $7,004.9$ & 100.0 & $6,071.5$ & 100.0 & 933.4 & 15.4 \\
\hline
\end{tabular}

Jika dilihat dari data penjualan bersih dari tahun 2006 sampai 2007 secara garis besar menunjukkan adanya peningkatan. Gambaran tersebut mengindikasikan pangsa pasar yang meluas dan kepuasan pelanggan yang meningkat. 
Hal tersebut terlihat juga pada kenaikan penjualan jasa pada Divisi Distribusi yang terutama dikarenakan makin bertambahnya jumlah prinsipal pihak ketiga yang baru. Namun khusus untuk minuman energi, menunjukkan adanya penurunan. Hal ini berkaitan dengan makin bermunculan produk sejenis di pasar yang sama sehingga perlu strategi baru untuk meningkatkan kinerja perusahaan.

\begin{tabular}{|c|c|c|c|c|c|c|}
\hline & \multicolumn{2}{|c|}{2007} & \multicolumn{2}{|c|}{2006} & \multirow{2}{*}{$\begin{array}{l}\text { Naik/(Turun) } \\
\text { Increase/ } \\
\text { (Decrease) }\end{array}$} & \multirow{2}{*}{$\begin{array}{c}\text { Perubahan } \\
\text { Change } \\
(\%)\end{array}$} \\
\hline & $\begin{array}{l}\text { Rp miliar } \\
\text { Rp billion }\end{array}$ & $\%$ Total & $\begin{array}{l}\text { Rp miliar } \\
\text { Rp billion }\end{array}$ & $\%$ Total & & \\
\hline Penjualan Lokal / Local Sales & $6,610.2$ & 94.4 & $5,781.6$ & 95.2 & 828.6 & 14.3 \\
\hline Penjualan Ekspor / Export Sales & 394.7 & 5.6 & 289.9 & 4.8 & 104.8 & 36.2 \\
\hline Total Penjualan / Total Sales & $7,004.9$ & 100.0 & $6,071.5$ & 100.0 & 933.4 & 15.4 \\
\hline
\end{tabular}

Kemudian jika dilihat dari penjualan bersih local dan ekspor, menunjukkan pula peningkatan dari tahun 2006 sampai tahun 2007 yang merupakan indikasi makin meluasnya jangkauan pasar produk PT Kalbe Farma Tbk.

\section{c. Perspektif bisnis internal}

Dalam perspektif ini, ada hal menarik yang terjadi pada PT Kalbe Farma Tbk bahwa setelah lebih dari satu tahun berlalu tidak ada gejolak dalam hal pemangkasan jumlah karyawan sebagai bagian dari proses konsolidasi group perusahaan. Hal ini menunjukkan juga bahwa karyawan PT Kalbe Farma Tbk memiliki loyalitas yang tinggi terhadap perusahaan sehingga sampai dengan 31 Desember 2007 jumlah karyawan tetap tidak mengalami penurunan yaitu sebanyak 10.282 karyawan.

\section{d. Perspektif inovasi dan pembelajaran}

Focus utama proyek riset dan pengembangan adalah pada produk-produk obat resep. Jika dilihat dari laporan penjualan bersih mengindikasikan peningkatan penjualan dari tahun 2006 sampai tahun 2007. Hal ini juga menunjukkan peningkatan kinerja perusahaan dalam hal inovasi dan pembelajaran.

\begin{tabular}{|c|c|c|c|c|c|c|}
\hline & \multicolumn{2}{|c|}{2007} & \multicolumn{2}{|c|}{2006} & \multirow{2}{*}{$\begin{array}{l}\text { Naik/(Turun) } \\
\text { Increase/ } \\
\text { (Decrease) }\end{array}$} & \multirow{2}{*}{$\begin{array}{c}\text { Perubahan } \\
\text { Change } \\
(\%)\end{array}$} \\
\hline & $\begin{array}{l}\text { Rp miliar } \\
\text { Rp billion }\end{array}$ & $\%$ Total & $\begin{array}{l}\text { Rp miliar } \\
\text { Rp billion }\end{array}$ & $\%$ Total & & \\
\hline Obat Bebas / OTC & $1,053.9$ & 15.0 & 944.1 & 15.5 & 109.8 & 11.6 \\
\hline Nutrisi / Nutritional & $1,600.0$ & 22.8 & $1,322.5$ & 21.8 & 277.5 & 21.0 \\
\hline Minuman Energi / Energy Drink & 802.3 & 11.5 & 895.7 & 14.8 & (93.4) & (10.4) \\
\hline Total Produk Kesehatan / Total Consumer Health & $3,456.2$ & 49.3 & 3.162 .3 & 52.1 & 293.9 & 9.3 \\
\hline Obat Resep / Prescription & $1,806.3$ & 25.8 & $1,457.1$ & 24.0 & 349.2 & 24.0 \\
\hline Distribusi / Distribution & $1,468.4$ & 21.0 & $1,205.9$ & 19.9 & 262.5 & 21.8 \\
\hline Kemasan / Packaging & 274.0 & 3.9 & 246.2 & 4.0 & 27.8 & 11.3 \\
\hline $\begin{array}{l}\text { Total Distribusi dan Kemasan / Total Distribution and } \\
\text { Packaging }\end{array}$ & $1,742.4$ & 24.9 & $1,452.1$ & 23.9 & 290.3 & 20.0 \\
\hline Penjualan Bersih / Net Sales & $7,004.9$ & 100.0 & $6,071.5$ & 100.0 & 933.4 & 15.4 \\
\hline
\end{tabular}




\section{Kompensasi}

Suatu peranan penting dari sistem pengendalian manajemen adalah untuk meotivasi para anggota organisasi untuk mencapai tujuan perusahaan. Kunci untuk memotivasi orang untuk berperilaku sedemikian rupa sehingga memajukan tujuan perusahaan terletak pada cara dengan mana insentif perusahaan berhubungan dengan tujuan individual.

Paket kompensasi total dari seorang manajer terdiri dari tiga komponen, yaitu gaji, tunjangan dan kompensasi insentif. Tiga komponen tersebut saling bergantung satu sama lain, tetapi kompensasi insentif secara khusus berkaitan dengan sistem pengendalian manajemen.

Kebijakan kompensasi insentif cenderung berbeda lintas strategi. PT Kalbe Farma Tbk yang menerapkan strategi diversifikasi berhubungan tidak begitu sesuai jika menggunakan rumus dalam mentapkan bonus. Tingkat saling ketergantungan yang besar antar unit usaha mengimplikasikan bahwa kinerja suatu unit bisnis dapat dipengaruhi oleh keputusan dan tindakan dari unit lainnya. Sehingga penetapan bonus berdasarkan rumus terkait dengan kinerja keuangan dapat menjadi kontra produktif.

Berkaitan dengan ukuran-ukuran profitabilitas, sebaiknya PT Kalbe Farma Tbk mendasarkan bonus insentif dari manajer unit bisnis baik pada kinerja unit tersebut dan kinerja unit organisasi yang lebih besar yang terkait dengannya. Seperti misalnya Manajer Unit Obat Bebas yang terkait dan berada dibawah Divisi Produk Kesehatan. Dalam implementasinya PT Kalbe Farma Tbk melakukan penilaian secara berkala terhadap kompensasi karyawan guna menjaga kesetaraan dengan standar industri. Standar keselamatan dan kesehatan kerja dalam semua aspek produksi juga ditingkatkan untuk mencapai kesejahteraan karyawan yang optimal. Program pengembangan karir terdiri dari penilaian kinerja secara berkala dengan dukungan pelatihan dan pendidikan yang memadai.

\section{KESIMPULAN}

PT Kalbe Farma Tbk berdiri tahun 1966 yang awalnya merupakan industri tunggal yang bergerak di bidang farmasi kemudian melakukan diversifikasi ke produk kesehatan serta distribusi dan kemasan. Strategi korporat yang dikembangkan adalah perusahaan dengan diversifikasi berhubungan. Perusahaan menetapkan strategi pengembangan ke arah bisnis internasional dan peningkatan kemampuan risetnya maka pada tingkat unit bisnis strategi yang diterapkan adalah "membangun". Strategi tersebut sesuai diterapkan bagi perusahaan yang ekspansi dan menghadapi situasi ketidakpastian yang lebih tinggi.

Struktur organisasi PT Kalbe Farma Tbk disusun secara fungsional dan terintegrasi sehingga lebih efisien. Penggunaan sumber daya yang sama dan terintegrasi seperti pemasaran, fasilitas produksi, keuangan serta fasilitas riset dan pengembangan oleh beberapa unit usaha yang ada telah menciptakan sinergi operasi. Hal ini membantu perusahaan untuk memperoleh manfaat dari skala dan ruang lingkup ekonomi.

Proses perencanaan strategis dilakukan secara vertikal maupun horizontal mengingat tingginya tingkat keterkaitan antar unit. Proses perencanaan ditetapkan dari tingkat korporat kemudian tiap unit bisnis mengajukan rencana strategisnya yang mendukung strategi korporat 
untuk disetujui manajemen puncak. Proses perencana ini tidak berbeda jauh dalam proses penyusunan anggaran.

Penilaian kinerja yang dilakukan dengan balaced scorcard menunjukkan peningkatan kinerja pada perspektif pelanggan, bisnis internal serta perspektif inovasi dan pembelajaran. Sedangkan pada perspektif keuangan menunjukkan penurunan. Hal ini lebih disebabkan kondisi eksternal yang tidak mendukung, seperti situasi ekonomi yang memburuk dan meningkatnya harga bahan baku serta kebijakan regulasi berkaitan dengan penurunan harga obat generik.

PT Kalbe Farma Tbk melakukan penilaian secara berkala terhadap kompensasi karyawan guna menjaga kesetaraan dengan standar industri. Standar keselamatan dan kesehatan kerja dalam semua aspek produksi juga ditingkatkan untuk mencapai kesejahteraan karyawan yang optimal. Program pengembangan karir terdiri dari penilaian kinerja secara berkala dengan dukungan pelatihan dan pendidikan yang memadai. Sistem kompensasi yang demikian lebih dapat memotivasi karyawan dalam meningkatkan kinerjanya.

Desain sistem pengendalian manajemen pada PT Kalbe Farma Tbk telah sesuai dengan strategi yang diterapkan perusahaan meskipun dalam jangka pendek belum mampu mengimplementasikan strategi perusahaan secara efektif terutama terkait dengan penyesuaianya dengan kondisi eksternal.

\section{DAFTAR PUSTAKA}

Antony, Govindarajan. 2007. Manajemen Control System, Twelfth Edison. Mc Graw Hill : New York.

ICMD berbagai edisi.

Laporan Tahunan PT Kalbe Farma Tbk tahun 2007 